Open Access

\title{
Halvard Buhaug* Climate Change and Conflict: Taking Stock
}

DOI 10.1515/peps-2016-0034

Previously published online August 25, 2016

\begin{abstract}
Is climate change a major security threat? How has research on climate and conflict progressed in recent years? And where should it move forward? This brief essay reflects on some ways in which climatic changes could constitute a threat to peace and stability. Rather than assuming a direct causal link, the essay argues that climate change may exert an indirect and conditional effect on conflict risk, increasing the security gap between affluent societies well able to cope with climate change and societies already suffering from violence and instability, who are unlikely to achieve successful adaptation on their own. For this reason, peace building is quite possibly the most effective climate resilience policy in unstable corners of the world.
\end{abstract}

Keywords: conflict, climate change, environment

\section{Introduction}

After a remarkable and much-celebrated decline in armed conflict following the collapse of the Cold War system (Gleditsch et al. 2002; Goldstein 2011; Pinker 2011), the trend now seems stabilized at around 35-40 active conflicts per year. What is more, conflict casualties actually show a notable uptick in recent years, with 2014 being the deadliest year since the late 1980s (Pettersson and Wallensteen 2015). With climate change and possible adverse knock-on consequences for agricultural productivity, economic activity, and food security approaching, fears are mounting that the future may see a reversal of the trend and bring more conflict and instability (CNA 2014; US DoD 2015).

In this short essay I review recent progress in scientific research on climate and conflict and, building on insights from that research, provide a few suggestions for where the field should be moving in coming years. Before doing so, however, a couple of clarifications are in order. First, while climate change

*Corresponding author: Halvard Buhaug, Peace Research Institute Oslo (PRIO), P.O. Box 9229 Grønland, NO-0134 Oslo, Norway, E-mail: halvard@prio.org

(cc)BY-NC-ND @2016, Halvard Buhaug, published by De Gruyter.

This work is licensed under the Creative Commons Attribution-NonCommercial-NoDerivatives 3.0 License. 
may conceivably lead to a host of negative security outcomes, I will only consider the risk of armed conflict here. Intrastate conflict is the dominant and most researched form of organized violence in the contemporary world, and while I am making no claim about the representativeness of this form of conflict for the wider spectrum of political violence, civil conflicts and wars are of particular concern as they generate more casualties in a random year than all other forms of political violence combined. Second, while the policy debate on climate change and security typically adopts a long-term perspective, much of the relevant empirical research addresses how climate variability, or short-term variations in weather patterns, affect conflict risk. This distinction is not trivial. Although the frequency and amplitude of climate variability may shift with climate change, social responses to short-term anomalies cannot be used to infer about future behavior in response to a shift in normal conditions. Put differently, the fact that beer consumption peaks during warm periods of the year (Uitenbroek 1996) need not imply that a two-degrees warmer world will see lots of drunk people.

\section{Climate change is bad}

In case you have been absent-minded over the past decade or so, let me be clear: climate change is bad. True, climate change and associated physical processes will vary in their manifestation and severity across regions, but overall the documentation provided so comprehensively in the UN Intergovernmental Panel on Climate Change's (IPCC) Fifth Assessment Report (AR5) is unequivocal: (i) the climate is changing at an unprecedented and accelerating rate, (ii) human greenhouse gas emissions are a signification contributor to that change, and (iii) the impacts of climate change "will amplify existing risks and create new risks for natural and human systems" (IPCC 2014, 13). Among other things, warming, shifting precipitation patterns, and more extreme weather events threaten to undermine local and global food security by reducing renewable surface water and groundwater resources in most dry and subtropical regions.

Adapting to and, in the longer run, mitigating climate change will require political will, human ingenuity, and material resources. Although attempts to estimate the aggregate cost of mitigation are fraught with uncertainty and a source of some controversy (Tol 2016), scenarios considered in AR5 indicate an annual loss of economic growth in the range of 0.04-0.14 percentage points (from a baseline estimated global growth of 1.6-3\% per year) over the course of the 21st century (IPCC 2014, 24).

Societies vary widely in their exposure to current and future natural hazards. While temperature increase will be most pronounced at higher latitudes, it constitutes a larger threat to ecosystems in warmer and dryer climates, where extreme 
events, such as prolonged droughts and heat waves, may approach or exceed the tolerance limit of plants and animal species (Bita and Gerats 2013). Projections are less certain regarding precipitation changes though the majority of simulations indicate that wet regions will get wetter while semi-arid and dry regions will become dryer (IPCC 2014). Sea-level rise is a global phenomenon that primarily affects low-elevation coastal zones and small islands. Just as climate change exposure varies across space, so do societies' abilities to deal with the challenges imposed by climate change. For this reason, various international bodies have been created to foster and coordinate concerted international action (e.g. the UN Framework Convention on Climate Change, UNFCCC, and the annual Conference of Parties, COP).

\section{Climate change won't cause armed conflict...}

Despite prophesies of "climate wars" (Dyer 2008; Welzer 2012), warnings that climate change is "the mother of all risks" (TIME 2015), and assertions about how "climate change is making our world more violent and less secure" (Levy 2014), I dare say that climate change does not cause armed conflict. Societal actors, be they state governments, military branches, political parties, civil society actors, or communal groups, do not resort to force in an organized and coordinated fashion only because temperature heats up or rainfall comes in unexpected ways. The alternative would be a form of environmental determinism where societies are tied to meteorological or ecological conditions in a mechanistic fashion. Indeed, the empirical evidence base to support the notion of a direct and general climateconflict link is thin (Adger et al. 2014; Bernauer, Böhmelt, and Koubi 2012; Buhaug et al. 2014; Salehyan 2014).

\section{4 ...But impacts of climate change might}

While shifts in climatic conditions do not cause armed conflict, climate variability and change may well influence the dynamics of interaction (including violent contention) between societal actors. However, such an effect will occur in conjunction and sometimes interaction with other prevalent conflict drivers and always be shaped by the specific context. To give one example, the conflict potential of drought depends on local land use (e.g. agricultural production, residential area, undeveloped rugged terrain), the affected population's vulnerability and coping capacity (e.g. access to ground water and irrigation systems, market 
forces, alternate modes of livelihood) and, of course, the response by the state (relief aid, subsidies, price control, etc.).

The distinction between a general causal effect and an indirect and conditional effect is more than mere semantics as it implicitly points to what must be addressed in order to avoid or end conflict. Rather than discussing the risk of "climate wars" - a term that should be avoided at all costs - scholars should take the notion of climate change as a "threat multiplier" (CNA 2007) seriously and investigate the conditions under which climatic changes may accentuate the threat to societal stability and peace, and the mechanisms through which a destabilizing effect might materialize.

The first wave of empirical climate-conflict studies relied almost exclusively on simple meteorological indicators, such as temperature or rainfall anomalies, as possible correlates of civil and intergroup conflict (e.g. Buhaug 2010; Burke et al. 2009; Couttenier and Soubeyran 2013; Fjelde and von Uexkull 2012; Hendrix and Salehyan 2012; O'Loughlin et al. 2012; Raleigh and Kniveton 2012; Theisen 2012). Although all of these analyses were limited to Africa or parts of the continent, by design accounting for some contextual factors, few explicitly considered interactive and conditional climate effects. As mentioned above, this body of work taken together has failed to converge on a general and robust climate-conflict connection.

A second and more promising wave of studies seeks to model climate-conflict relationships in a multi-stage fashion, considering the conflict impact of adverse socioeconomic changes assumed to be affected by rapid climatic shifts (e.g. Buhaug et al. 2015; Caruso, Petrarca, and Ricciuti 2016; Koubi et al. 2012; Schleussner et al. 2016; Smith 2014; van Weezel 2015; Wischnath and Buhaug 2014). The literature is not short on proposed indirect links from climate change to conflict - among which intermediate implications for food insecurity, production shocks, and migration feature most prominently - but more research is needed along these lines before we are ready to conclude about the nature and strength of such connections.

A third possible pathway from climate change to conflict that has received less attention is the possibility of adverse side effects of implemented mitigation policies. For example, some research highlights how dam construction and hydropower production carries significant conflict potential (between countries as well as within them) by altering seasonal river flow and downstream water availability (Kuenzer et al. 2013). Likewise, reforestation programs and the establishment of conservation parks can uproot or in other ways negatively affect the livelihoods of the local population (Ghazoul et al. 2010). In the longer term, increasing cost of air travel due to, e.g. environmental taxation may significantly alter international tourism patterns, hurting the economies of destinations that become much costlier to reach (Scott, Gössling and Hall 2012). 


\section{What about the reverse relationship?}

Based on the best available scientific evidence it is clear that climate variability and change at most exert indirect and conditional effects on conflict risk, although we do not yet know the pervasiveness and significance of these effects. However, climate impacts and conflict are endogenous to one-another (Gartzke and Böhmelt 2015), where the reverse association, from armed conflict to climate risks, is many times more powerful. We know that conflicts and wars cause enormous human suffering, destroy material goods and infrastructure, trigger capital flight and brain drain, and deter investment in future development. For this reason, civil war is development in reverse (Collier et al. 2003). Low level of economic development, poor growth, and political instability in turn are major contributors to environmental vulnerability. In the words of the IPCC, "conflict strongly influences vulnerability to climate change impacts" (Adger et al. 2014, 12).

Taken together, these insights give a glimpse of what we might expect in the future. Stable and wealthy societies possess the skills and resources and presumably also the political will to address climate change-related challenges and impacts in an appropriate and peaceful manner. Conflict-affected societies, however, many of which struggle with endemic political chaos, corruption, and poor economic growth, are unable to adapt to and cope with these challenges on their own, thereby reinforcing the vicious cycle of instability and underdevelopment. In this sense - and absent international assistance - the future is likely to further solidify existing conflict patterns [though see Hegre et al. (2016) for a more sophisticated approach to modeling future conflict scenarios].

\section{Discussion}

Several conclusions can be drawn from this summary of the field. First, scholars should continue the recent trend toward theorizing and investigating indirect pathways from climate variability and change to conflict. An important part of this work should be to better specificy the conditions under which such effects might play out (Seter 2016). Second, there is a notable lack of knowledge on possible insecurity implications of climate change mitigation. Again, a direct causal link is not very likely but indirect effects via adverse economic or livelihood impacts are not inconceivable. Third, scholars, commentators, and policy makers alike should shy away from sensationalism and the tendency to see events exclusively through the scarcity lens [see Sneyd, Legwegoh and Fraser (2013) for an 
insightful analysis]. However, the other extreme, explicitly refraining from attempting to rank the relative importance of various conflict drivers is no better. Werell and Femia (2015) are correct in observing that "climate change is not an exogenous threat, hermetically sealed from other risks," but it does not follow, as they contend, that we should "move away from [... 'ranking' threats to national security." Seeking to avoid mono-causal explanations is commendable, but the unweighted all-inclusive approach is equally problematic as it implicitly suggests that peace-building strategies must pay equal attention to all identified issues in order to solve a conflict. Such advice is not particularly helpful to those developing or implementing policy, nor is it likely to be successful. Conversely, robust scientific evidence indicates that peace building probably is the most effective climate resilience strategy in war-torn regions. Without peace and stable, wellfunctioning political institutions it is hard to see how societies can address existing and future security challenges affected by climate change.

Acknowledgments: I would like to thank Raul Caruso and the steering committee of NEPS for inviting me to give the 2016 Annual NEPS Lecture in Milan, Italy. This work is funded by the European Research Council through grant no. 648291.

\section{References}

Adger, W.N., Pulhin, J.M., Barnett, J., Dabelko, J.D., Hovelsrud, G.K., Levy, M., Oswald Spring, Ú., Vogel, C.H., (2014), Human Security, In Field, C.B., Barros, V.R., Dokken, D.J., Mach, K.J., Mastrandrea, M.D., Bilir, T.E., Chatterjee, M., Ebi, K.L., Estrada, Y.O., Genova, R.C., Girma, B., Kissel, E.S., Levy, A.N., MacCracker, S., Mastrandrea, P.R., White, L.L. (eds.) Climate Change 2014: Impacts, Adaptation, and Vulnerability. IPCC, Geneva, Switzerland.

Bernauer, T., Böhmelt, T., Koubi, V., (2012), Environmental Changes and Violent Conflict, Environmental Research Letters, vol. 7, no. 1, pp. 015601.

Bita, C.E., Gerats, T., (2013), Plant Tolerance to High Temperature in a Changing Environment: Scientific Fundamentals and Production of Heat Stress-Tolerant Crops, Frontiers in Plant Science, vol. 4, pp. 273.

Buhaug, H., (2010), Climate not to Blame for African Civil Wars, Proceedings of the National Academy of Sciences of the USA, vol. 107, no. 38, pp. 16477-16482.

Buhaug, H., Nordkvelle, J., Bernauer, T., Böhmelt, T., Brzoska, M., Busby, J.W., Ciccone, A., Fjelde, H., Gartzke, E., Gleditsch, N.P., Goldstone, J.A., Hegre, H., Holtermann, H., Koubi, V., Link, J.S.A., Link, P.M., Lujala, P., O’Loughlin, J., Raleigh, C., Scheffran, J., Schilling, J., Smith, T.G., Theisen, O.M., Tol, R.S.J., Urdal, H., von Uexkull, N., (2014), One Effect to Rule them all? A Comment on Climate and Conflict, Climatic Change, vol. 127, pp. 391-397.

Buhaug, H., Benjaminsen, T.A., Sjaastad, E., Theisen, O.M., (2015), Climate Variability, Food Production Shocks, and Violent Conflict in Sub-Saharan Africa, Environmental Research Letters, vol. 10, pp. 125015. 
Burke, M.B., Miguel, E., Satyanath, S., Dykema, J.A., Lobell, D.B., (2009), Warming Increases the Risk of Civil War in Africa, Proceedings of the National Academy of Sciences of the USA, vol. 106, no. 49, pp. 20670-20674.

Caruso, R., Petrarca, I., Ricciuti, R., (2016), Climate Change, Rice Crops, and Violence: Evidence from Indonesia, Journal of Peace Research vol. 53, no. 1, pp. 66-83.

CNA, (2007), National Security and the Threat of Climate Change, CNA Corporation, Alexandria, VA.

CNA, (2014), National Security and the Accelerating Risks of Climate Change, CNA Corporation, Alexandria, VA.

Collier, P., Elliot, V.L., Hegre, H., Hoeffler, A., Reynal-Querol, M., Sambanis, N., (2003), Breaking the Conflict Trap: Civil War and Development Policy, The World Bank, Washinton, DC.

Couttenier, M., Soubeyran, R., (2013), Drought and Civil War in Sub-Saharan Africa, The Economic Journal, vol. 124, pp. 201-244.

Dyer, G., (2008), Climate Wars, Random House, Canada.

Fjelde, H., von Uexkull, N., (2012), Climate Triggers: Rainfall Anomalies, Vulnerability and Communal Conflict in Sub-Saharan Africa, Political Geography, vo. 31, pp. 444-453.

Gartzke, E., Böhmelt, T., (2015), Climate and Conflict: Whence the Weather? Peace Economics, Peace Science and Public Policy, vol. 21, no. 4, pp. 445-451.

Ghazoul, J., Butler, R.A., Mateo-Vega, J., Koh, L.P., (2010), REDD: A Reckoning of Environment and Development Implications, Trends in Ecology \& Evolution, vol. 25, no. 7, pp. 396-402.

Gleditsch, N.P., Wallensteen, P., Eriksson, M., Sollenberg, M., Strand, H., (2002), Armed Conflict 1946-2001: A New Dataset, Journal of Peace Research vol. 39, no. 5, pp. 615-637.

Goldstein, J.S., (2011), Winning the War on War: The Decline of Armed Conflict Worldwide, Dutton, New York.

Hegre, H., Buhaug, H., Calvin, K.V., Nordkvelle, J., Waldhoff, S.T., Gilmore, E., (2016), Forecasting Civil Conflict along the Shared Socioeconomic Pathways, Environmental Research Letters, vol. 11, pp. 054002.

Hendrix, C., Salehyan, I., (2012), Climate Change, Rainfall, and Social Conflict in Africa, Journal of Peace Research, vol. 49, no. 1, pp. 35-50.

IPCC, (2014), Climate Change 2014: Synthesis Report. Contribution of Working Groups I, II and III to the Fifth Assessment Report of the Intergovernmental Panel on Climate Change. IPCC, Geneva, Switzerland.

Koubi, V., Bernauer, T., Kalbhenn, A., Spilker, G., (2012), Climate Variability, Economic Growth, and Civil Conflict, Journal of Peace Research, vol. 49, no. 1, pp. 113-127.

Kuenzer, C., Campbell, I., Roch, M., Leinenkugel, P., Tuan, V.Q., Dech, S., (2013), Understanding the Impact of Hydropower Developments in the Context of Upstream-Downstream Relations in the Mekong River Basin, Sustainability Science, vol. 8, pp. 565-584.

Levy, M., (2014), Welcome to the Pressure Cooker: How Climate Change is making our World more Violent and Less Secure. Presentation at Simon Fraser University, Vancouver, 26 February. https://www.youtube.com/watch?v=u8f3qmHCKB0.

O’Loughlin, J., Witmer, F.D., Linke, A.M., Laing, A., Gettelman, A., Dudhia, J., (2012), Climate Variability and Conflict Risk in East Africa, 1990-2009, Proceedings of the National Academy of Sciences of the USA, vol. 109, no. 45, pp. 18344-18349.

Pettersson, T., Wallensteen, P., (2015), Armed Conflict, 1946-2014, Journal of Peace Research, vol. 52, no. 4, pp. 536-550.

Pinker, S., (2011), The Better Angels of our Nature, Viking, New York. 
Raleigh, C., Kniveton, D., (2012), Come Rain or Shine: An Analysis of Conflict and Climate Variability in East Africa, Journal of Peace Research, vol. 49, no. 1, pp. 51-64.

Salehyan, I., (2014), Climate Change and Conflict: Making Sense of Disparate Findings, Political Geography, vol. 43, pp. 1-5.

Schleussner, C.-F., Donges, J.F., Donner, R.V., Schellnhuber, H.J., (2016), Armed-Conflict Risks Enhanced by Climate-Related Disasters in Ethnically Fractionalized Countries, Proceedings of the National Academy of Sciences of the USA, Doi: 10.1073/pnas.1601611113.

Scott, D., Gössling, S., Hall, C.M., (2012), International Tourism and Climate Change, WIRES Climate Change, vol. 3, no. 3, pp. 213-232.

Seter, H., (2016), Connecting Climate Variability and Conflict: Implications for Empirical Testing, Political Geography, vol. 53, pp. 1-9.

Smith, T.G., (2014), Feeding Unrest: Disentangling the Causal Relationship between Food Price Shocks and Sociopolitical Conflict in Urban Africa, Journal of Peace Research, vol. 51, pp. 679-695.

Sneyd, L.Q., Legwegoh, A., Fraser, E.D.G., (2013), Food Riots: Media Perspectives on the Causes of Food Protest in Africa, Food Security, vol. 5, pp. 485-497.

TIME, (2015), Climate Change is the 'Mother of all Risks' to National Security, TIME Magazine, 6 November. http://time.com/4101903/climate-change-national-security/.

Theisen, O.M., (2012), Climate Clashes? Weather Variability, Land Pressure, and Organized Violence in Kenya, 1989-2004, Journal of Peace Research, vol. 49, no. 1, pp. 81-96.

Tol, R.S.J., (2016), The Impacts of Climate change according to the IPCC, Climate Change Economics, vol. 7, no. 1, pp. 1640004.

Uitenbroek, D.G., (1996), Seasonal Variation in Alcohol Use, Journal of Studies on Alcohol, vol. 57 , no. 1, pp. 47-52.

US DoD, (2015), National Security Implications of Climate-Related Risks and a Changing Climate, US Department of Defense, Washington, DC.

van Weezel, S., (2015), Economic Shocks \& Civil Conflict Onset in Sub-Saharan Africa, 1981-2010, Defence and Peace Economics, vol 26, pp. 153-177.

Welzer, H. (2012), Climate Wars: What People Will Be Killed for in the $21^{\text {st }}$ Century, Polity Press, Cambridge.

Werell, C., Femia, F., (2015), “Is Climate Change the Biggest Security Threat?” is still a Bad Question. Blog post, Climate and Security, 16 November. https://climateandsecurity. org/2015/11/16/is-climate-change-the-biggest-security-threat-is-still-a-bad-question/.

Wischnath, G., Buhaug, H., (2014), Rice or Riots: On Food Production and Conflict Severity Across India, Political Geography, vol. 43, pp. 6-15. 